\title{
1 Diversity increases yield but reduces reproductive effort in crop \\ 2 mixtures
}

3

4 Jianguo Chen ${ }^{1,2}$, Nadine Engbersen ${ }^{1}$, Laura Stefan ${ }^{1}$, Bernhard Schmid ${ }^{3,4}$, Hang Sun ${ }^{2}$

$5 \&$ Christian Schöb $b^{1 *}$

6

$7{ }^{1}$ Department of Environmental Systems Science, Swiss Federal Institute of

8 Technology Zurich (ETH), 8092 Zurich, Switzerland

$9 \quad{ }^{2}$ CAS Key Laboratory for Plant Diversity and Biogeography of East Asia, Kunming

10 Institute of Botany, Chinese Academy of Sciences, Kunming 650201, Yunnan, China

$11{ }^{3}$ Department of Geography, University of Zurich, Winterthurerstrasse 190, 8057

12 Zurich, Switzerland

$13{ }^{4}$ Institute of Ecology, College of Urban and Environmental Sciences, Peking

14 University, 100871 Beijing, China

15

$16 *$ Corresponding author: christian.schoeb@usys.ethz.ch 


\section{Abstract}

Resource allocation to reproduction is a critical trait for plant fitness ${ }^{1,2}$. This trait, called harvest index in the agricultural context ${ }^{3-5}$, determines how plant biomass is converted to seed yield and consequently financial revenue of numerous major staple crops. While plant diversity has been demonstrated to increase plant biomass $^{6-8}$, plant diversity effects on seed yield of crops are ambiguous9. This discrepancy could be explained through changes in the proportion of resources invested into reproduction in response to changes in plant diversity, namely through changes of species interactions and microenvironmental conditions ${ }^{10-13}$. Here we show that increasing crop plant diversity from monoculture over 2- to 4-species mixtures increased annual primary productivity, resulting in overall higher plant biomass and, to a lesser extent, higher seed yield in mixtures compared with monocultures. The difference between the two responses to diversity was due to a reduced reproductive effort of the eight tested crop species in mixtures, possibly because their common cultivars have been bred for maximum performance in monoculture. While crop diversification provides a sustainable measure of agricultural intensification $^{14}$, the use of currently available cultivars may compromise larger gains in seed yield. We therefore advocate regional breeding programs for crop varieties to be used in mixtures that should exploit facilitative interactions ${ }^{15}$ among crop species. 


\section{Main text}

Based on the vast ecological literature demonstrating positive relationships between plant diversity and annual primary productivity ${ }^{16,17}$, increasing crop plant diversity through intercropping, i.e. the simultaneous cultivation of more than one crop species on the same land, has been proposed as a promising sustainable intensification measure in agriculture ${ }^{14,15,18}$. However, evidence on positive crop plant diversity-seed yield relationships is ambiguous ${ }^{9,19,20}$. This could be due to non-linear reproductive allocation patterns, where increased annual primary productivity in mixtures would not translate into corresponding increases in seed yield.

The amount of resources allocated to seeds is a critical component of plant fitness $^{1,2,21-23}$ and directly determines grain yield and the economic value of annual grain crops, including the major staple crops wheat, maize, rice, soybeans, beans and barley $^{23-25}$. For crops, resource allocation has therefore been a target trait under selection during plant domestication ${ }^{26}$ and modern plant breeding ${ }^{3}$. In general, reproductive allocation is allometric ${ }^{27}$, i.e. seed yield increases alongside vegetative plant biomass ${ }^{28,29}$. However, varying abiotic and biotic conditions such as climate, resource availability, competition or genotype identity can modify the allometric resource allocation pattern ${ }^{13,30-33}$.

Plant community diversity is known to trigger changes in resource allocation patterns $^{34}$ through plastic responses of the constituent plants ${ }^{35,36}$. Plastic responses of plants can contribute to niche differentiation processes, which in turn promote positive biodiversity-productivity relationships ${ }^{37,38}$. In other words, plastic changes in 
61

62

63

64 81 yield by $3.4 \%$ in Spain and by $21.4 \%$ in Switzerland, while seed yield increases

resource allocation strategies in response to increasing plant diversity, such as a reduced reproductive effort due to relatively higher resource investment in vegetative plant parts with higher plant diversity, could diminish the biodiversity-seed yield relationship. However, this ecologically and economically very relevant question has, to our knowledge, not been scientifically addressed.

Understanding the abiotic and biotic factors concomitantly controlling the proportion of resources allocated to seeds is crucial for efforts to maintain or increase crop yields and to contribute to food security under a range of environmental and farming conditions. However, we lack an ecological understanding on how plant diversity, in interaction with the physical environment, influences reproductive effort of the constituent species. For this study, we therefore selected eight annual grain crop species commonly cultivated in Europe to determine their reproductive effort under varying species diversity levels, different climatic and soil fertility conditions and with locally adapted (i.e. home) versus foreign cultivars (i.e. away). To do this we conducted a common garden experiment replicated over two countries (Switzerland and Spain), two soil fertility levels (unfertilized and fertilised), two cultivars (Swiss and Spanish) and four plant diversity levels (i.e. isolated single plants, monocultures and 24 different 2- and 16 different 4-species mixtures) in a replicated fully factorial design.

Increasing crop diversity from monoculture to 2 -species mixture increased seed 
82 reached $12.7 \%$ and $44.3 \%$ from monoculture to 4 -species mixture in Spain and

83 Switzerland, respectively (Fig. 1).

Fig. 1: Seed yield response to crop diversity

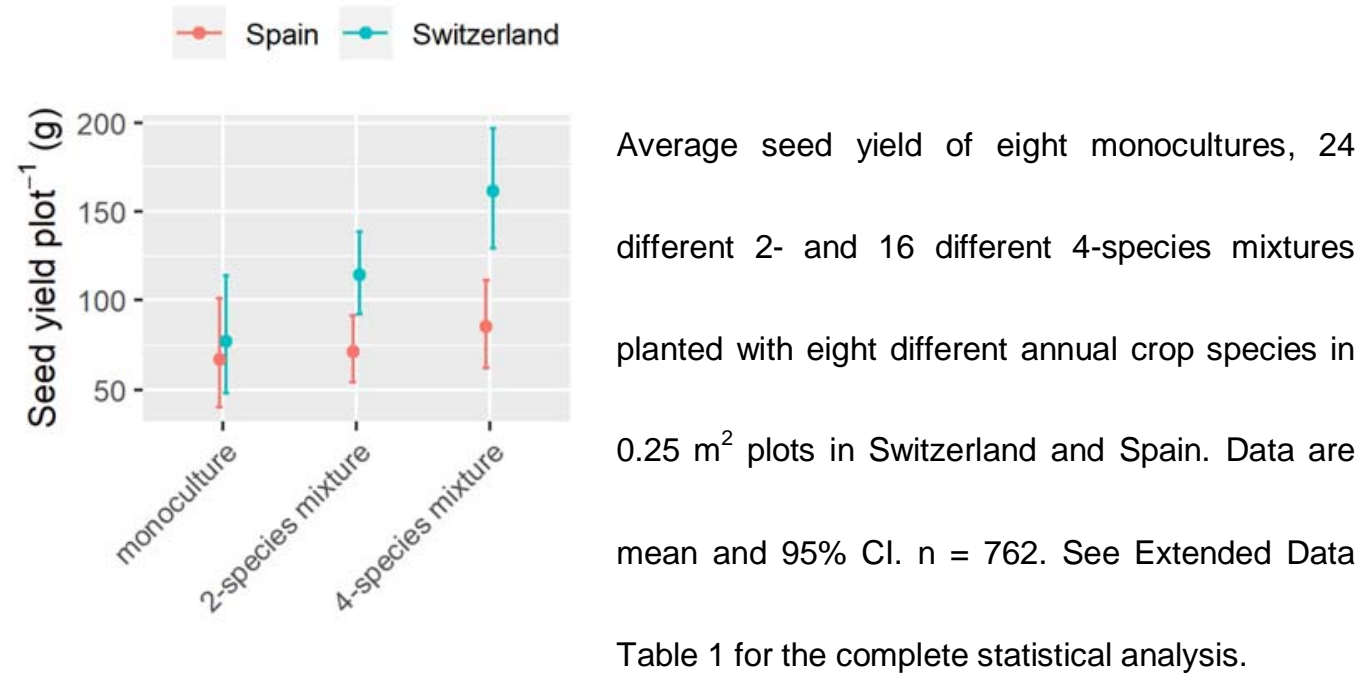

92

Even though crop diversity increased seed yield (Fig. 1), aboveground

94 vegetative biomass increases with increasing crop diversity were 8.8- and 3.1-fold

95 higher in Spain and Switzerland, respectively, than the increases in seed yield. The

96 reduced benefit of crop diversity on seed yield compared with vegetative biomass was

97 due to a reduction in both types of mechanisms underlying diversity effects on yield,

98 i.e. complementarity and sampling effects ${ }^{17}$ (Fig. 2). In Switzerland, complementarity

99 effects contributed $25 \%$ more than sampling effects to the net biodiversity effect on

100 seed yield, while in Spain only sampling effects could be detected. Complementarity

101 effects in Switzerland were 59\% lower for seed yield than for vegetative biomass. 

available under aCC-BY-ND 4.0 International license.

102 Sampling effects were $70 \%$ and $83 \%$ lower for seed yield than for vegetative biomass

103 in Spain and Switzerland, respectively. 
Fig. 2: Crop plant diversity effects on seed yield and vegetative biomass

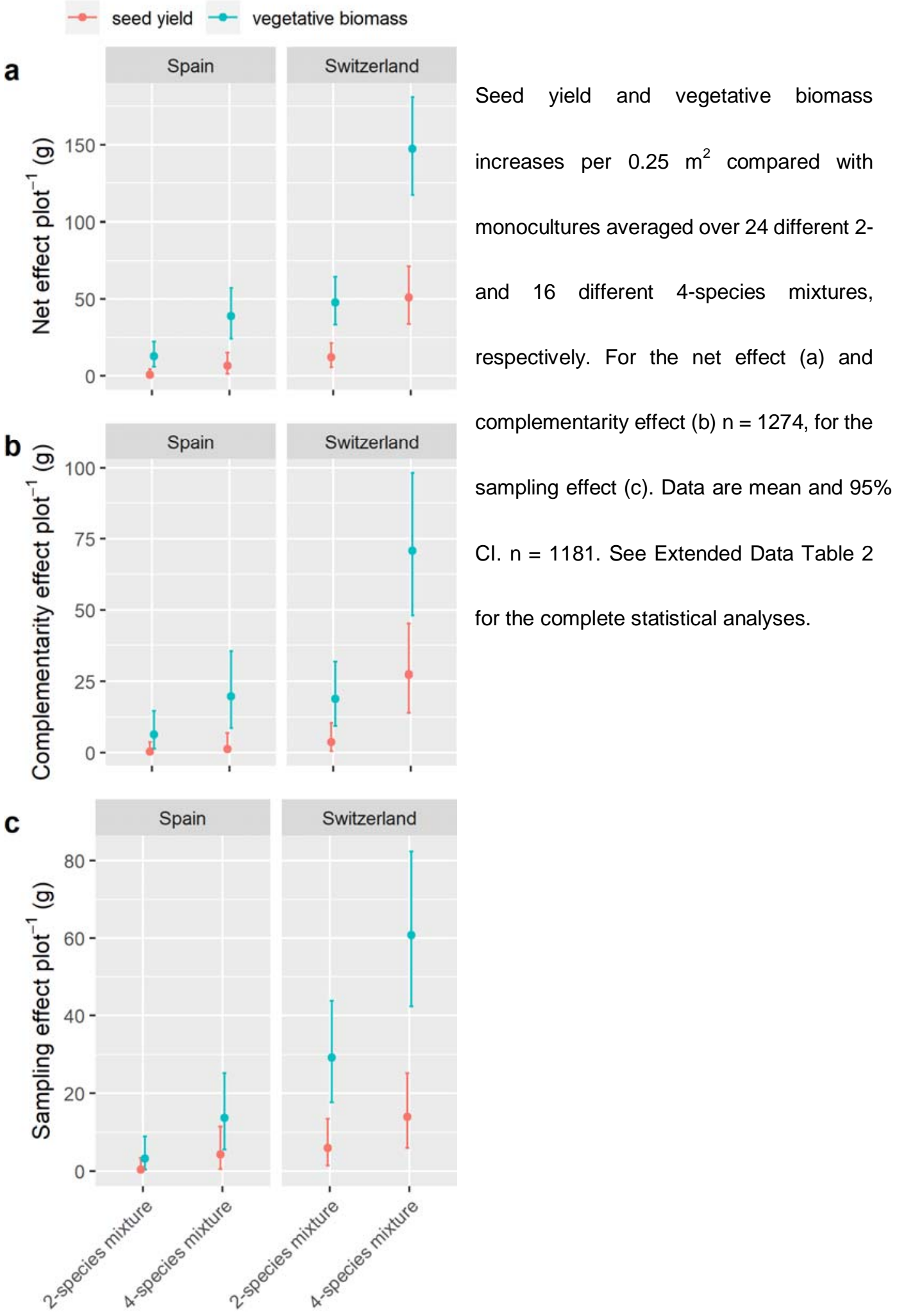



clear trend towards reduced reproductive effort with increasing plant diversity (Fig. 3a). Reproductive effort in monocultures was higher than in mixtures - an effect only weakly dependent on species and country (Fig. 3b). The strongest reductions in reproductive effort from monocultures to 4-species mixtures where observed in Spain for oat $(-22 \%)$, linseed $(-9 \%)$, wheat $(-4 \%)$, lupin $(-4 \%)$ and coriander $(-4 \%)$, and in Switzerland for lupin $(-13 \%)$, lentil $(-7 \%)$, linseed $(-7 \%)$, wheat $(-5 \%)$ and coriander $(-3 \%)$. Finally, reproductive effort was lower in 4-species mixtures than in 2-species mixtures (Fig. 3), except for locally adapted cultivars on fertilized soils (Extended Data Fig. 1).

Reproductive effort varied among species, being highest for legumes (i.e. $L$. culinaris (mean and 95\% confidence interval): $0.60[0.56,0.63]$ and L. angustifolius: 0.57 [0.53, 0.62]), followed by herbs (i.e. C. sativum: 0.64 [0.61, 0.68], C. sativa: 0.55 [0.51, 0.59], L. usitatissimum: 0.51 [0.47, 0.55], C. quinoa: 0.49 [0.45, 0.53]), and lowest for cereals (i.e. A. sativa: 0.49 [0.48, 0.49], T. aestivum: $0.40[0.37,0.44]$ ). The species-specific reproductive effort was also context-dependent and varied with ecotype and country and therefore with the home vs away environment. Reproductive $[0.51,0.53])$, which is consistent with previous studies which found that plants 144 allocated relatively more resources to reproductive structures under more severe 145 environmental conditions ${ }^{39}$. In contrast, the higher reproductive efforts for legumes 146 (lupin: $+8 \%$, lentil: $+2 \%$ ) and cereals (oat: $+18 \%$, wheat: $+3.5 \%$ ) in the home 
147 compared with the away environment provides evidence for the importance of local

148 adaptation $^{40}$ of crops for yield benefits (Extended Data Fig. 3).

149 Fig. 3: Reproductive effort of crop species in response to plant diversity and 150 country

151

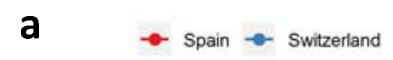

b
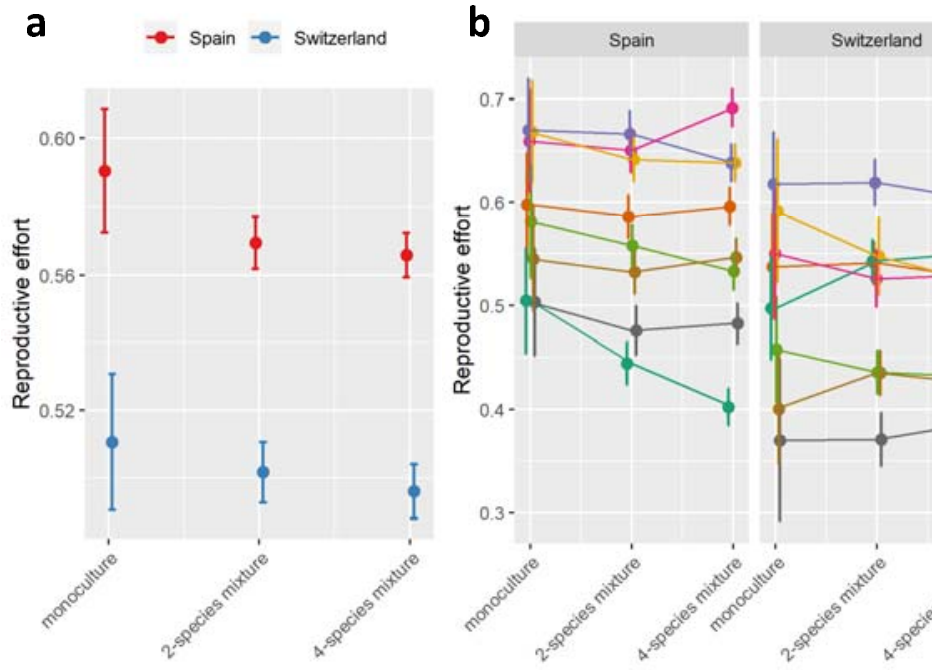

152

Reproductive effort in response to plant diversity and country averaged over all species (a)

and for each crop species separately (b). Data are mean and 95\% Cl. $n=4751$. Reproductive

effort of each species for each species combination is shown in Extended Data Fig. 2. See

Extended Data Table 3 for the complete statistical analysis. Oat $=$ Avena sativa, camelina $=$

Camelina sativa, coriander $=$ Coriandrum sativum, lentil $=$ Lens culinaris, linseed $=$ Linum

usitatissimum, lupin $=$ Lupinus angustifolius, quinoa $=$ Chenopodium quinoa, wheat $=$ Triticum

aestivum. 
162 wheat, linseed, oat, lupin and lentil). This is in line with previous research

163 demonstrating a drop of the harvest index with increasing planting density of crops ${ }^{41}$.

164 Beyond that, reduced plant height (in particular wheat, linseed, lupin, oat, lentil and

165 quinoa) together with increased leaf area (in particular lupin, linseed, lentil and oat)

166 and SLA (in particular quinoa, oat and coriander) in mixtures compared with

167 monocultures went along with reduced reproductive effort. Finally, reproductive

168 effort was reduced when LDMC was higher in mixtures than in monocultures for

169 linseed and quinoa, and when LDMC was lower in mixtures than in monocultures for

170 lentil, coriander and lupin.

171 Reproductive effort was highly responsive to the experimental treatments,

172 including the different plant diversity levels, suggesting a plastic response of currently

173 available crop plants to heterospecific neighbours in this trait. Specifically, the results

174 demonstrate a deviation of resources away from reproduction towards the shoot with

175 increasing neighbourhood plant diversity. This plastic response in resource allocation

176 of crop plants in more diverse cropping systems compromises the yield benefits of

177 crop mixtures. In the extreme case of oat in Spain, yield benefits in mixtures

178 compared with monocultures were reduced by 14 and $20 \%$ in 2- and 4 -species

179 mixtures, respectively, only through the lower reproductive effort of this species in

180 mixtures compared with monocultures. 


\section{functional traits}
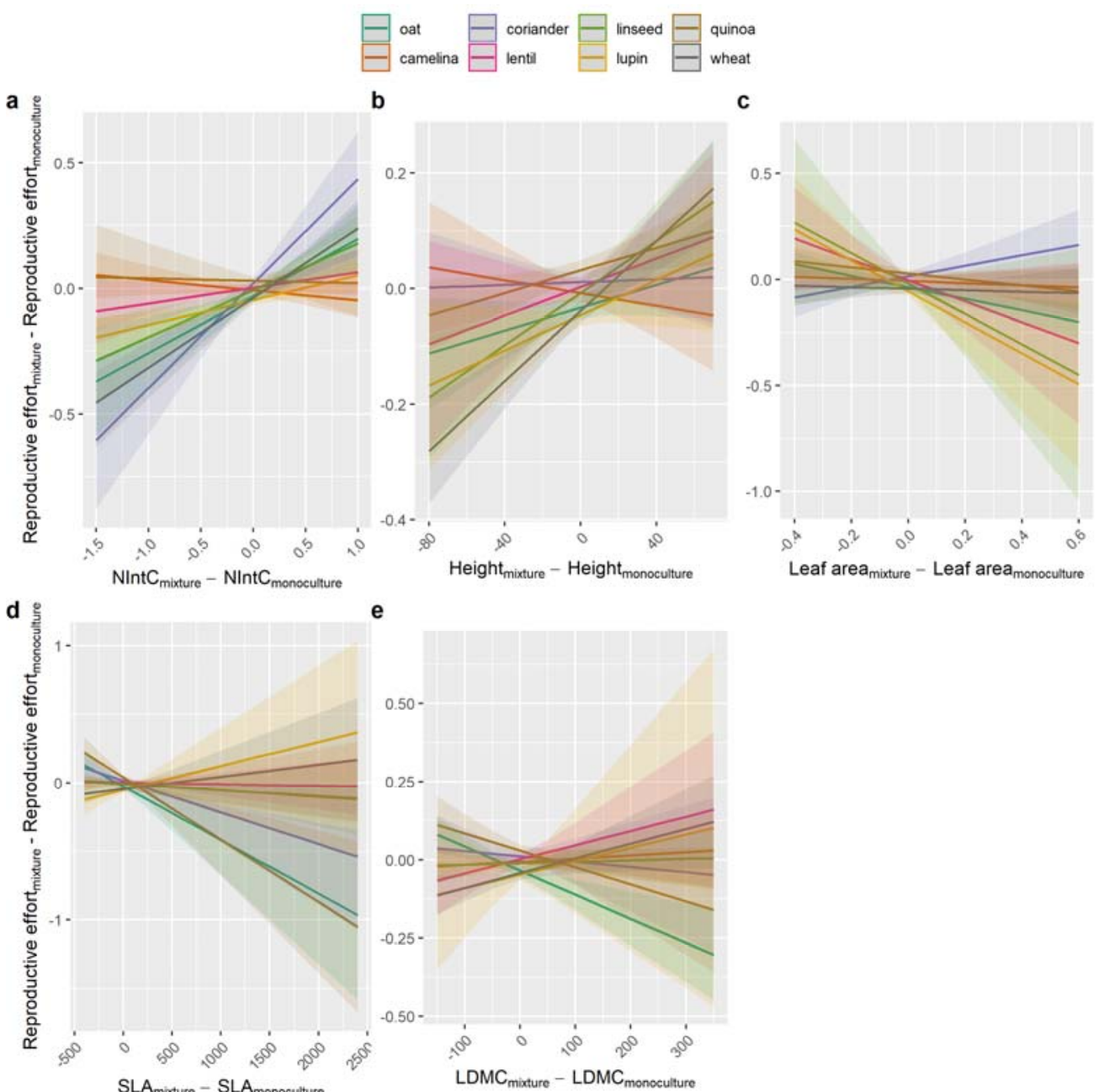

e

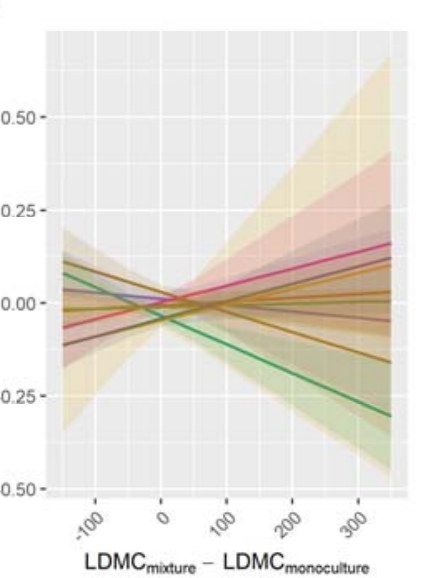

The difference in reproductive effort of eight crop species in mixtures compared with 
207 programs may benefit from going back to locally adapted cultivars with higher

208 reproductive effort in mixtures.

\section{References}


214 3. Donald, C. M. The breeding of crop ideotypes. Euphytica 17, 385-403 (1968).

215 4. Unkovich, M., Baldock, J. \& Forbes, M. Variability in harvest index of grain crops

216 and potential significance for carbon accounting: Examples from Australian

217 agriculture. Adv. Agron. 105, 173-219 (2010).

218 5. Tamagno, S., Sadras, V. O., Ortez, O. A. \& Ciampitti, I. A. Allometric analysis

219 reveals enhanced reproductive allocation in historical set of soybean varieties. Field

220 Crop Res. 248, online, doi: 10.1016/j.fcr.2020.107717 (2020).

221 6. Hector, A. et al. Plant diversity and productivity experiments in European

222 grasslands. Science 286, 1123-1127 (1999).

223 7. Grace, J. B. et al. Integrative modelling reveals mechanisms linking productivity

224 and plant species richness. Nature 529, 390-393 (2016).

225 8. Huang, Y. et al. Impacts of species richness on productivity in a large-scale

226 subtropical forest experiment. Science 362, 80-83 (2018).

227 9. Letourneau, D. K. et al. Does plant diversity benefit agroecosystems? A synthetic

228 review. Ecol. Appl. 21, 9-21 (2011).

229 10. McConnaughay, K. D. M. \& Coleman, J. S. Biomass allocation in plants:

230 Ontogeny or optimality? A test along three resource gradients. Ecology 80, 2581-2593

231 (1999).

232 11. Bonser, S. P. \& Aarssen, L. W. Allometry and plasticity of meristem allocation

233 throughout development in Arabidopsis thaliana. J. Ecol. 89, 72-79 (2001).

234 12. Reekie, E. G. \& Bazzaz, F. A. Reproductive Allocation in Plants. (Elsevier

235 Academic press, 2005). 
236

237

238

239

240

241

242

243

244

245

246

247

248

249

250

251

252

253

254

255

256

257

13. Wang, T. H., Zhou, D. W., Wang, P. \& Zhang, H. X. Size-dependent reproductive effort in Amaranthus retroflexus: the influence of planting density and sowing date.

Can. J. Bot. 84, 485-492 (2006).

14. Gurr, G. M. et al. Multi-country evidence that crop diversification promotes ecological intensification of agriculture. Nat. Plants 2, 16014 (2016).

15. Li, L., Tilman, D., Lambers, H. \& Zhang, F. S. Plant diversity and overyielding: insights from belowground facilitation of intercropping in agriculture. New Phytol. 203, 63-69 (2014).

16. Tilman, D., Reich, P. B., Knops, J., Wedin, D., Mielke, T., Lehman, C. Diversity and productivity in a long-term grassland experiment. Science 294, 843-845 (2001).

17. Loreau, M. \& Hector, A. Partitioning selection and complementarity in biodiversity experiments. Nature 412, $72-76$ (2001).

18. Brooker, R. W. et al. Improving intercropping: a synthesis of research in agronomy, plant physiology and ecology. New Phytol. 206, 107-117 (2015).

19. Martin-Guay, M. O., Paquette, A., Dupras, J. \& Rivest, D. The new green revolution: Sustainable intensification of agriculture by intercropping. Sci. Total Environ. 615, 767-772 (2018).

20. Li, C., Hoffland, E., Kuyper, T. W., Yu, Y., Zhang, C., Li, H., Zhang, F., van der Werf, W. Syndromes of production in intercropping impact yield gains. Nat. Plants (2020). https://doi.org/10.1038/s41477-020-0680-9

21. Bazzaz, F. A., Chiariello, N. R., Coley, P. D. \& Pitelka, L. F. Allocating resources to reproduction and defense. Bioscience 37, 58-67 (1987). 
258

259

260

261

262

263

264

265

266

267

268

269

270

271

272

273

274

275

276

277

278

22. Hartnett, D. C. Size-Dependent allocation to sexual and vegetative reproduction in 4 clonal composites. Oecologia 84, 254-259 (1990).

23. Vega, C. R. C., Sadras, V. O., Andrade, F. H. \& Uhart, S. A. Reproductive allometry in soybean, maize and sunflower. Ann. Bot. 85, 461-468 (2000).

24. Gifford, R. M., Thorne, J. H., Hitz, W. D. \& Giaquinta, R. T. Crop productivity and photoassimilate partitioning. Science 225, 801-808 (1984).

25. Andrade, F. H. et al. Kernel number determination in maize. Crop Sci. 39, 453-459 (1999).

26. Milla, R., Osborne, C. P., Turcotte, M. M. \& Violle, C. Plant domestication through an ecological lens. Trends Ecol. Evol. 30, 463-469 (2015).

27. Niklas, K. J. Plant Allometry: The Scaling of Form and Process. (University of Chicago Press, 1994).

28. Echarte, L. \& Andrade, F. H. Harvest index stability of Argentinean maize hybrids released between 1965 and 1993. Field Crop Res. 82, 1-12 (2003).

29. Weiner, J., Campbell, L. G., Pino, J. \& Echarte, L. The allometry of reproduction within plant populations. J. Ecol. 97, 1220-1233 (2009).

30. Sugiyama, S. \& Bazzaz, F. A. Size dependence of reproductive allocation: the influence of resource availability, competition and genetic identity. Funct. Ecol. 12, 280-288 (1998).

31. Weiner, J. Allocation, plasticity and allometry in plants. Perspect. Plant Ecol. 6, 207-215 (2004). 
279

280

281

282

283

284

285

286

287

288

289

290

291

292

293

294

295

296

297

298

299

300

32. Weiner, J. et al. Is reproductive allocation in Senecio vulgaris plastic? Botany $\mathbf{8 7}$, 475-481 (2009).

33. Schmid, B., Weiner, J. Plastic relationships between reproductive and vegetative mass in Solidago altissima. Evolution 47, 61-74 (1993).

34. Schmid, B. \& Pfisterer, A.B. Species vs community perspectives in biodiversity experiments. Oikos 100, 620-621 (2003).

35. Lipowsky, A., Roscher, C., Schumacher, J, Michalski, S. G., Gubsch, M., Buchmann, N., Schulze, E.-D. \& Schmid, B. Plasticity of functional traits of forb species in response to biodiversity. Perspect. Plant Ecol. Evol. Syst. 17, 66-77 (2015). 36. Abakumova, M., Zobel, K., Lepik, A. \& Semchenko, M. Plasticity in plant functional traits is shaped by variability in neighbourhood species composition. New Phytol. 211, 455-463 (2016).

37. Zhu, J. Q., van der Werf, W., Anten, N. P. R., Vos, J. \& Evers, J. B. The contribution of phenotypic plasticity to complementary light capture in plant mixtures. New Phytol. 207, 1213-1222 (2015).

38. Niklaus, P. A., Baruffol, M., He, J. S., Ma, K. P. \& Schmid, B. Can niche plasticity promote biodiversity-productivity relationships through increased complementarity? Ecology 98, 1104-1116 (2017).

39. Sadras, V. O., Bange, M. P. \& Milroy, S. P. Reproductive allocation of cotton in response to plant and environmental factors. Ann. Bot. 80, 75-81 (1997).

40. Joshi, J., Schmid, B., Caldeira, M.C., Dimitrakopoulos, P.G., Good, J., Harris, R., Hector, A., Huss-Danell, K., Jumpponen, A., Minns, A., Mulder, C.P.H., Pereira, J.S., 
301 Prinz, A., Scherer-Lorenzen, M., Siamantziouras, A.-S.D., Terry, A.C., Troumbis,

302 A.Y. and Lawton, J.H. Local adaptation enhances performance of common plant

303 species. Ecol. Lett. 4: 536-544 (2001).

304

41. Li, J., Xie, R. Z., Wang, K. R., Ming, B., Guo, Y. Q., Zhang, G. Q. and Li, S. K.

Variations in maize dry matter, harvest index, and grain yield with plant density.

Agron. J. 107: 829-834 (2015).

42. Roscher, C. \& Schumacher, J. Positive diversity effects on productivity in

9, 792-804 (2016).

\section{Methods}

The crop diversity experiment was carried out in outdoor experimental gardens in

Switzerland is temperate humid. In Zurich, the garden was located at the Irchel

Rubio, the garden was situated at the Aprisco de Las Corchuelas research station 
323

324

325

326

327

328

329

330

331

332

334

335

336

337

338

339

340

341

342

343

temperature (average daily mean, min and max temperatures are $14.0^{\circ} \mathrm{C}, 9.3{ }^{\circ} \mathrm{C}$ and 18.6 ${ }^{\circ} \mathrm{C}$ in Zurich vs $14.6{ }^{\circ} \mathrm{C}, 9.6{ }^{\circ} \mathrm{C}$ and $19.6{ }^{\circ} \mathrm{C}$ in Cáceres). All climatic data are from the Deutsche Wetterdienst (www.dwd.de) and are average values over the years 1961 to 1990.

Each experimental garden consisted of beds with square plots of $0.25 \mathrm{~m}^{2}$ that were raised by $30 \mathrm{~cm}$ above the soil surface. In Switzerland, we had 554 plots spread over 20 beds of $1 \times 7 \mathrm{~m}$, with 26 to 28 plots per bed. In Spain, we had 624 plots spread over 16 beds of $1 \times 10 \mathrm{~m}$, with 38 to 40 plots per bed. The soil surface consisted of penetrable standard local agricultural soil, covered by a penetrable fleece. On top of the fleece, each box was filled with $30 \mathrm{~cm}$ standard, but not enriched, local agricultural soil. The local soil in Switzerland was a neutral loamy soil consisting of $45 \%$ sand, $45 \%$ silt and $10 \%$ clay. Soil $\mathrm{pH}$ was 7.25 , total $\mathrm{C}$ and $\mathrm{N}$ were $2.73 \%$ and $0.15 \%$, respectively, and total and available $\mathrm{P}$ were $339.7 \mathrm{mg} / \mathrm{kg}$ and $56.44 \mathrm{mg} / \mathrm{kg}$, respectively. The local soil in Spain was a slightly acidic sandy soil consisting of $78 \%$ sand, $20 \%$ silt and $2 \%$ clay. Soil $\mathrm{pH}$ was 6.39 , total $\mathrm{C}$ and $\mathrm{N}$ were $1.02 \%$ and $0.06 \%$, respectively, and total and available $\mathrm{P}$ were $305.16 \mathrm{mg} / \mathrm{kg}$ and $66.34 \mathrm{mg} / \mathrm{kg}$, respectively. Therefore, compared with the soil in Switzerland, the soil in Spain was sandier and poorer in soil organic matter.

Study species

The eight selected crop species were: Triticum aestivum (wheat), Avena sativa (oat), Lens culinaris (lentil), Coriandrum sativum (coriander), Camelina sativa (camelina), 
344

345

346

347

348

349

Lupinus angustifolius (blue lupin), Linum usitatissimum (linseed), and Chenopodium quinoa (quinoa). These species are important annual seed crops that can be cultivated in Europe. The eight species belong to four phylogenetic groups, with two species per group. We had monocots [A. sativa (Poaceae) and T. aestivum (Poaceae)] vs dicots. Then, among the dicots, we differentiated between superasterids [C. sativum (Apiaceae) and C. quinoa (Amaranthaceae)] and superrosids. Among the superrosids, we finally differentiated between legumes $[L$. culinaris (Fabaceae) and $L$. angustifolius (Fabaceae)] and non-legumes [C. sativa (Brassicaceae) and $L$. usitatissimum (Linaceae)]. Each species was represented by two cultivars (hereafter called ecotypes), one local cultivar from Switzerland and another local cultivar from Spain (Extended Data Table 5). For cultivar selection we considered, whenever possible, traditional varieties with some inherent genetic variability within species.

\section{Experimental design}

The experimental design included a nested plant diversity treatment: (1) single control plants for each species (between 4 and 10 replicates depending on species and country) vs plant communities (i.e. factor 'Community'); (2) within plant communities there were monocultures for each species (2 replicates) vs species mixtures (i.e. factor 'Diversity'); (3) within species mixtures there were all possible 2-species mixtures consisting of two phylogenetic groups each (2 replicates of 24 different species combinations), and all possible 4-species mixtures consisting of four phylogenetic groups each (2 replicates of 16 species combinations) (i.e. factor 'Species number'). To test for the context dependency of reproductive allocation patterns at different 
366 plant diversity levels, this setup was replicated at two levels of soil fertility

367 (unfertilized control plots vs fertilized plots; factor 'Fertilisation'). In the fertilised

368 plots we applied $120 \mathrm{~kg} / \mathrm{ha} \mathrm{N}, 205 \mathrm{~kg} / \mathrm{ha} \mathrm{P}$ and $120 \mathrm{~kg} / \mathrm{ha} \mathrm{K}$ divided over three

369 fertilisation events of $50 \mathrm{~kg} \mathrm{~N} / \mathrm{ha}$ applied one day before sowing, another $50 \mathrm{~kg} \mathrm{~N} / \mathrm{ha}$

370 after tillering of wheat and the remaining $20 \mathrm{~kg} \mathrm{~N} / \mathrm{ha}$ during the flowering stage of

371 wheat. The described experimental setup was further replicated for the Swiss and the

372 Spanish ecotypes (i.e. factor 'Ecotype') both in Switzerland and in Spain (i.e. factor

373 'Country'). The interaction between 'Ecotype' and 'Country' was assessed as

374 additional factor 'Home', with two factor levels: 'home' representing Spanish

375 cultivars in Spain and Swiss cultivars in Switzerland and 'away' representing the

376 opposite combinations.

377 Experimental setup and data collection

378 In Spain, the seeds were sown between 2 and 4 February 2018 and in Switzerland

379 between 4 and 6 April 2018. All the seeds were sown by hand at a standard sowing

380 density for the corresponding crop species: 400 seeds $/ \mathrm{m}^{2}$ for cereals, $240 \mathrm{seeds} / \mathrm{m}^{2}$ for

381 superasterids, 592 seeds $/ \mathrm{m}^{2}$ for non-legume superrosids, and 160 seeds $/ \mathrm{m}^{2}$ for

382 legumes. Sowing was conducted in four rows of $45 \mathrm{~cm}$ length per plot and an

383 inter-row distance of $12 \mathrm{~cm}$. Sowing depth was $0.5 \mathrm{~cm}$ for $C$. sativa, $5 \mathrm{~cm}$ for $L$.

384 culinaris and $2 \mathrm{~cm}$ for all other species. For the isolated single-plant treatment we

385 placed five seeds in the center of the plot, randomly selected one plant approx. three

386 weeks after germination and manually removed the spare individuals. Weeds were

387 manually removed from all monoculture and mixture plots approx. 80 days after 
388

389

390

391

392

393

sowing, while weeds in the plots with isolated single plants were removed several times during the growing season to avoid competition of the single plants with the otherwise abundant weeds in these plots. No other interventions were made over the course of the experiment, e.g. no harrowing or pesticide application. Harvest was conducted for each species once it reached maturity and lasted in Spain between 15 June and 11 July for all species except $C$. quinoa, which was harvested between 26 July and 21 August. Harvest in Switzerland was between 11 and 13 July for C. sativa and between 26 July and 5 September for all other species. In each plot (except for isolated single plants) and for each species we randomly marked three individuals during the flowering stage (i.e. 6154 individuals). All the marked individuals were harvested separately and seeds (i.e. reproductive biomass) were separated from all other aboveground biomass, incl. stems, leaves and chaff (i.e. vegetative biomass). While seeds were air-dried, vegetative biomass was oven-dried at $80{ }^{\circ} \mathrm{C}$ for $48 \mathrm{~h}$ prior to weighing.

\section{Data analyses}

Plot-level yield responses to the experimental treatments were assessed using a linear mixed effects model with (1) country, ecotype and home vs away; (2) fertilisation, and (3) diversity and species number, and their interactions as fixed effects and species composition and bed ID as random effects. Plot-level yield as the total mass of all seeds produced in a plot was square-root transformed to meet assumptions of parametric statistics. Significance of each factor was assessed using type-I analysis of variance with Satterthwaite's method. 
411 versus grain yield, we applied the additive partitioning method ${ }^{17}$ of biodiversity

412 effects and calculated net effects, complementarity effects and sampling effects

413 separately for vegetative biomass and grain yield. Differences in their responses to

414 experimental treatments were tested with a linear mixed-effects model with net effect,

415 complementarity effect or sampling effect as response variables and organ (shoot $v s$

416 seeds), country, ecotype, home $v s$ away, fertilisation, species number ( 2 vs 4) and

417 their possible interactions as fixed effects. Bed ID and plot ID were included as

418 random terms. The three response variables were square-root transformed to meet

419 assumptions of parametric statistics. Significance of each factor was assessed using

420 type-I analysis of variance with Satterthwaite's method. seeds (i.e. 5107 individuals included, while 1047 individuals were excluded due to

423 mortality, lack of mature seeds or missing data) as $\mathrm{RE}=$ reproductive

424 biomass/(vegetative biomass + reproductive biomass). To detect the effects of (1)

425 species, (2) country, ecotype and home, (3) fertilization, (4) species number (two- vs 426 four-species) nested within diversity (monoculture vs mixture) nested within

427 community (single individual vs community) and the possible interactions between 428 these factors on reproductive effort of the crops, we used a linear mixed-effects model 429 and type-I analysis of variance. Reproductive effort was square-root-transformed to 430 meet normality and homoscedasticity of variance assumptions. We included bed ID 431 and plot ID as well as the species composition as random factors into the model. 

when neighbour diversity increased, we quantified differences in plant interaction intensity and plant functional traits between mixtures and monocultures and related

Plant interaction intensity in the plots was calculated for each individual by means of

447 and resistance in harsh environment ${ }^{44-46}$. Vegetative plant height reflects plant's

448 ability to capture light energy in competition through relatively high growth rates ${ }^{47,48}$.

449 In a linear mixed-effects model we assessed the response of $\Delta \mathrm{RE}_{\text {mixture-monoculture }}$ to

$\triangle \mathrm{SLA}_{\text {mixture-monoculture }}$ and $\triangle \mathrm{LDMC}_{\text {mixture-monoculture }}$ and their interactions with species.

452 Bed and plot ID were included as random terms. Statistical significance of each factor 

ggemmeans() in ggeffects $^{50}$ and plotted with plot_model() in sjPlot ${ }^{51}$.

\section{References Methods}

42. Díaz-Sierra, R., Verwijmeren, M., Rietkerk, M., de Dios, V. R., Baudena, M. A new family of standardized and symmetric indices for measuring the intensity and importance of plant neighbour effects. Methods Ecol Evol 8, 580-591 (2017).

43. Poorter, H., Garnier, E. Ecological significance of inherent variation in relative growth rate and its components. Handbook of Functional Plant Ecology (eds. F.I. Pugnaire and F. Valladares), pp81-120. Marcel Dekker, Inc., New York (1999).

44. Grime, J. P. Evidence for existence of 3 primary strategies in plants and its relevance to ecological and evolutionary theory. Am. Nat. 111, 1169-1194 (1977).

45. Wilson, P. J., Thompson, K., Hodgson, J. G. Specific leaf area and leaf dry matter content as alternative predictors of plant strategies. New Phytol. 143, 155-162 (1999).

46. Poorter, H., Niinemets, U., Poorter, L., Wright, I. J., Villar, R. Causes and consequences of variation in leaf mass per area (LMA): a meta-analysis. New Phytol. 182, 565-588 (2009).

47. Lavorel, S., Grigulis, K. How fundamental plant functional trait relationships scale-up to trade-offs and synergies in ecosystem services. J. Ecol. 100, 128-140 (2012).

48. Conti, G., Díaz, S. Plant functional diversity and carbon storage - an empirical test in semi-arid forest ecosystems. J. Ecol. 101, 18-28 (2013). 
476

477 Foundation for Statistical Computing, Vienna, Austria, 2019).

478 https://www.r-project.org/

479

480

481

482

483

484

485

486

487

488

489

490

491

492

493

494

495

models. Journal of Open Source Software 3, 772 (2018).

http://doi.org/10.5281/zenodo.1308157. (2020).

\section{Acknowledgements} assistance.

\section{Author contributions} CS wrote the paper with input from BS, NE, LS and HS.

\section{Competing interests}

The authors declare no competing financial interests.

49. $\mathrm{R}$ Core Team. R: A language and environment for statistical computing. ( $\mathrm{R}$

50. Lüdecke, D. ggeffects: Tidy data frames of marginal effects from regression

51. Lüdecke, D. sjPlot: Data visualization for statistics in social science. Zenodo.

This work was financially supported by the Swiss National Science Foundation (PP PPOOP3_170645 to CS). JC was supported by the China Scholarship Council.

Thanks to C. Barriga Cabanillas, E. P. Carbonell, H. Ramos Marcos, E. Hidalgo

Froilán, A. García-Astillero Honrado, R. Hüppi and S. Baumgartner for field

CS and JC conceptualised the study; CS designed the experiment with input from BS;

NE, LS and CS carried out the experiment, CS, BS and JC analysed the data; JC and 


\section{Materials \& Correspondence}

497 Correspondence and requests for materials should be addressed to Christian Schöb.

498 Data availability statement

499 The data that support the findings of this study are available from the corresponding

500 author upon reasonable request.

501 Supplementary Information is available for this paper.

$502-\mathrm{R}$ code

503

- data 


\section{Extended Data}

505 Extended Data Table 1 | Type-I Analysis of Variance table testing the

506 experimental treatment effects on plot-level seed yield

507

\begin{tabular}{lrrrrrr}
\hline Factor & SS & \multicolumn{1}{c}{ MS } & numDF & denDF & F-value & P-value \\
\hline Country & 835.01 & 835.01 & 1 & 20.8 & 71.23 & $<0.001$ \\
Ecotype & 966.21 & 966.21 & 1 & 688.7 & 82.43 & $<0.001$ \\
Home & 127.35 & 127.35 & 1 & 689.1 & 10.86 & 0.001 \\
Fertilisation & 30.41 & 30.41 & 1 & 20.8 & 2.59 & 0.122 \\
Diversity & 32.81 & 32.81 & 1 & 45.1 & 2.80 & 0.101 \\
Species number & 34.04 & 34.04 & 1 & 44.9 & 2.90 & 0.095 \\
Country $\times$ Fertilisation & 32.76 & 32.76 & 1 & 20.8 & 2.80 & 0.110 \\
Ecotype $\times$ Fertilisation & 9.46 & 9.46 & 1 & 688.0 & 0.81 & 0.369 \\
Home $\times$ Fertilisation & 0.73 & 0.73 & 1 & 688.1 & 0.06 & 0.803 \\
Country $\times$ Diversity & 120.78 & 120.78 & 1 & 676.9 & 10.30 & 0.001 \\
Country $\times$ Species number & 60.13 & 60.13 & 1 & 678.5 & 5.13 & 0.024 \\
Ecotype $\times$ Diversity & 24.07 & 24.07 & 1 & 689.4 & 2.05 & 0.152 \\
Ecotype $\times$ Species number & 13.59 & 13.59 & 1 & 693.0 & 1.16 & 0.282 \\
Home $\times$ Diversity & 27.04 & 27.04 & 1 & 689.6 & 2.31 & 0.129 \\
Home $\times$ Species number & 5.02 & 5.02 & 1 & 693.0 & 0.43 & 0.513 \\
Fertilisation $\times$ Diversity & 3.05 & 3.05 & 1 & 676.8 & 0.26 & 0.610 \\
Fertilisation $\times$ Species number & 10.48 & 10.48 & 1 & 678.2 & 0.89 & 0.345 \\
Country $\times$ Fertilisation $\times$ Diversity & 0.89 & 0.89 & 1 & 676.7 & 0.08 & 0.782 \\
Country $\times$ Fertilisation $\times$ Species & & & & & & \\
number & 0.32 & 0.32 & 1 & 678.2 & 0.03 & 0.869 \\
Ecotype $\times$ Fertilisation $\times$ Diversity & 4.83 & 4.83 & 1 & 689.2 & 0.41 & 0.521 \\
Ecotype $\times$ Fertilisation $\times$ Species & & & & & & \\
number & 0.08 & 0.08 & 1 & 693.0 & 0.01 & 0.934 \\
Home $\times$ Fertilisation $\times$ Diversity & 9.15 & 9.15 & 1 & 689.2 & 0.78 & 0.377 \\
Home $\times$ Fertilisation $\times$ Species number & 0.04 & 0.04 & 1 & 693.0 & 0.00 & 0.956 \\
\hline \hline Rand & & & & & &
\end{tabular}

\begin{tabular}{lrrrr}
\hline Random factor & $\mathrm{n}$ & & Variance & $\mathrm{SD}$ \\
\hline Species composition & & 48 & 5.65 & 2.38 \\
Bed ID & & 29 & 0.12 & 0.35 \\
Residual & & & 11.72 & 3.42 \\
\hline
\end{tabular}

509 Significance was tested with the Satterthwaite approximation method. $\mathrm{n}=762$.

$510 \quad$ Marginal $\mathrm{R}^{2}=0.19$, conditional $\mathrm{R}^{2}=0.46$. 
Extended Data Table 2 | Type-I Analysis of Variance table testing the experimental treatment effects on net effect, complementarity effect and sampling effect

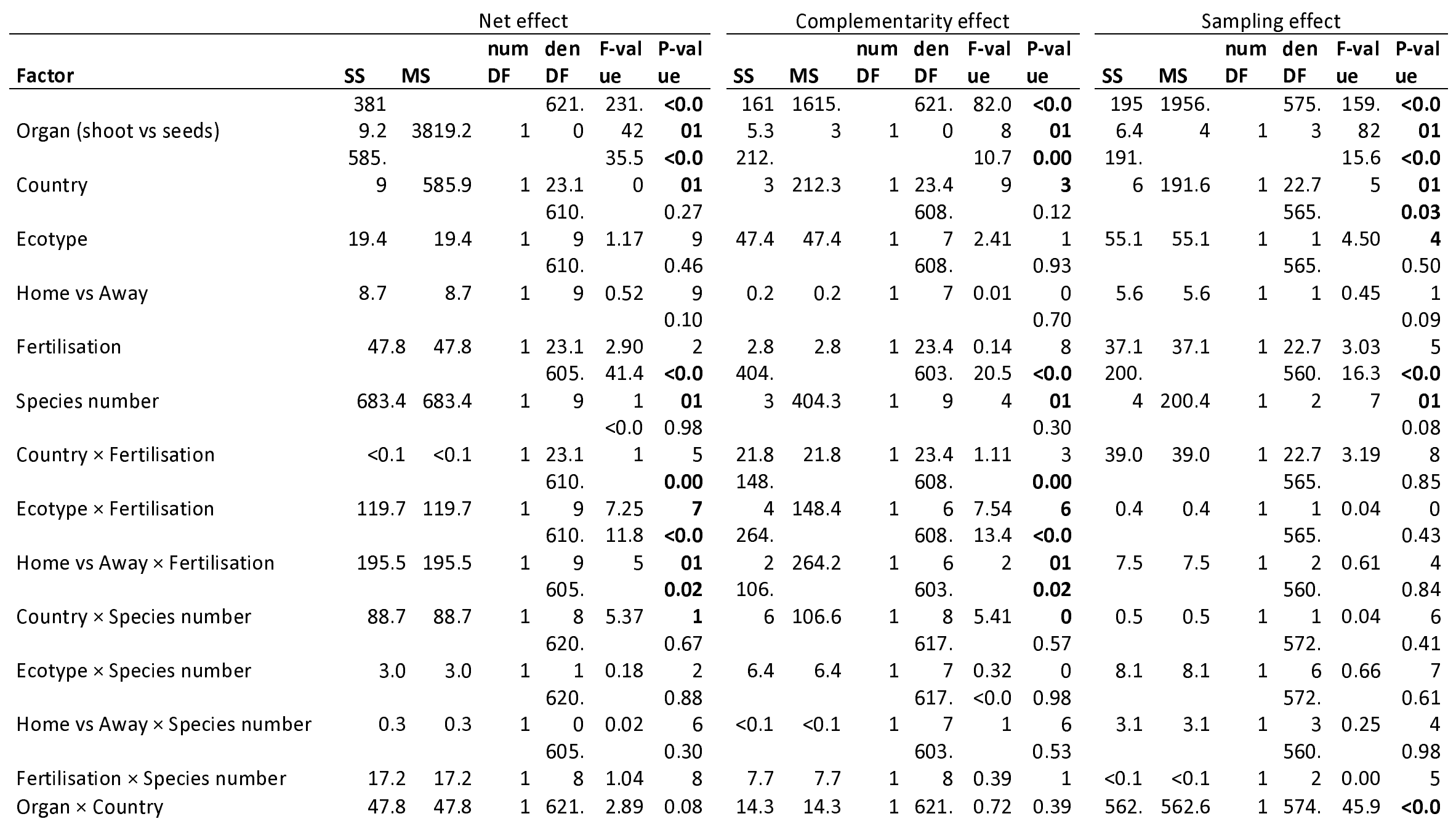


Organ $\times$ Ecotype

Organ $\times$ Home vs Away

Organ $\times$ Fertilisation

Organ $\times$ Species number

Country $\times$ Fertilisation $\times$ Species number

Ecotype $\times$ Fertilisation $\times$ Species number

Home vs Away $\times$ Fertilisation $x$

Species number

Organ $\times$ Country $\times$ Fertilisation

Organ $\times$ Ecotype $\times$ Fertilisation

Organ $\times$ Home vs Away $\times$

Fertilisation

\section{Organ $\times$ Country $\times$ Species number}

Organ $\times$ Ecotype $\times$ Species number Organ $\times$ Home vs Away $\times$ Species number

Organ $\times$ Fertilisation $\times$ Species number

Organ $\times$ Country $\times$ Fertilisation $x$ Species number

Organ $\times$ Ecotype $\times$ Fertilisation $\times$ Species number






\begin{tabular}{|c|c|c|c|c|c|c|c|c|c|c|c|c|c|c|c|c|c|c|}
\hline Organ $\times$ Home vs Away $\times$ & & & & 1. & & 0.87 & & & & 621. & & 0.42 & & & & 75. & & 0.39 \\
\hline Fertilisation $\times$ Species number & 0.4 & 0.4 & 1 & 0 & 0.03 & 1 & 12.5 & 12.5 & 1 & 0 & 0.63 & 7 & 9.0 & 9.0 & 1 & 0 & 0.73 & 2 \\
\hline & & Varia & & & & & & Varia & & & & & & Varia & & & & \\
\hline Random effects & $n$ & nce & SD & & & & $\mathrm{n}$ & nce & SD & & & & $\mathrm{n}$ & nce & SD & & & \\
\hline Plot ID & 637 & 31.70 & 5.63 & & & & 637 & 34.13 & 5.84 & & & & 593 & 22.38 & 4.73 & & & \\
\hline Bed ID & 29 & 1.14 & 1.07 & & & & 29 & 2.24 & 1.50 & & & & 29 & 2.13 & 1.46 & & & \\
\hline Residual & & 16.50 & 4.06 & & & & & 19.68 & 4.44 & & & & & 12.24 & 3.50 & & & \\
\hline
\end{tabular}

515

516

517

518

519
Significance was tested with the Satterthwaite approximation method. For the net effect $\mathrm{n}=1274$, marginal $\mathrm{R}^{2}=0.20$, conditional $\mathrm{R}^{2}=0.73$; for the complementarity effect $n=1274$, marginal $R^{2}=0.12$, conditional $R^{2}=0.69$; for the sampling effect $n=1181$, marginal $R^{2}=0.16$, conditional $R^{2}=$ 0.72 . 
Extended Data Table 3 | Type-I Analysis of Variance table of the experimental treatment effects on reproductive effort

521

\begin{tabular}{|c|c|c|c|c|c|c|}
\hline Factor & SS & MS & numDF & denDF & F-value & P-value \\
\hline Species & 18.87 & 2.70 & 7 & 635.5 & 191.14 & $<0.001$ \\
\hline Country & 0.96 & 0.96 & 1 & 21.5 & 68.10 & $<0.001$ \\
\hline Ecotype & 3.04 & 3.04 & 1 & 450.8 & 215.55 & $<0.001$ \\
\hline Home vs Away & 0.43 & 0.43 & 1 & 464.2 & 30.48 & $<0.001$ \\
\hline Fertilisation & 0.00 & 0.00 & 1 & 21.3 & 0.25 & 0.621 \\
\hline Diversity & 0.07 & 0.07 & 1 & 77.7 & 4.81 & 0.031 \\
\hline Species number & 0.01 & 0.01 & 1 & 28.4 & 1.01 & 0.323 \\
\hline Species $\times$ Country & 7.04 & 1.01 & 7 & 3931.6 & 71.28 & $<0.001$ \\
\hline Species $\times$ Ecotype & 4.15 & 0.59 & 7 & 3938.0 & 42.03 & $<0.001$ \\
\hline Species $\times$ Home vs Away & 1.18 & 0.17 & 7 & 3963.5 & 11.91 & $<0.001$ \\
\hline Species $\times$ Fertilisation & 0.36 & 0.05 & 7 & 3728.1 & 3.66 & $<0.001$ \\
\hline Species $\times$ Diversity & 0.09 & 0.01 & 7 & 103.7 & 0.89 & 0.519 \\
\hline Species $\times$ Species number & 0.19 & 0.03 & 7 & 693.2 & 1.88 & 0.070 \\
\hline Country $\times$ Fertilisation & 0.01 & 0.01 & 1 & 21.6 & 0.51 & 0.482 \\
\hline Ecotype $\times$ Fertilisation & 0.00 & 0.00 & 1 & 451.7 & 0.04 & 0.842 \\
\hline Home vs Away $\times$ Fertilisation & 0.04 & 0.04 & 1 & 465.1 & 2.66 & 0.104 \\
\hline Country $\times$ Diversity & 0.01 & 0.01 & 1 & 1461.3 & 0.50 & 0.479 \\
\hline Country $\times$ Species number & 0.00 & 0.00 & 1 & 482.6 & 0.02 & 0.897 \\
\hline Ecotype $\times$ Diversity & 0.01 & 0.01 & 1 & 1460.2 & 0.36 & 0.549 \\
\hline Ecotype $\times$ Species number & 0.00 & 0.00 & 1 & 479.6 & 0.00 & 0.996 \\
\hline Home vs Away $\times$ Diversity & 0.01 & 0.01 & 1 & 1462.0 & 0.95 & 0.331 \\
\hline Home vs Away $\times$ Species number & 0.01 & 0.01 & 1 & 491.8 & 0.65 & 0.420 \\
\hline Fertilisation $\times$ Diversity & 0.00 & 0.00 & 1 & 1443.9 & 0.06 & 0.803 \\
\hline Fertilisation $\times$ Species number & 0.08 & 0.08 & 1 & 463.5 & 5.61 & 0.018 \\
\hline Species $\times$ Country $\times$ Fertilisation & 0.43 & 0.06 & 7 & 3926.5 & 4.33 & $<0.001$ \\
\hline Species $\times$ Ecotype $\times$ Fertilisation & 0.14 & 0.02 & 7 & 3940.0 & 1.40 & 0.200 \\
\hline Species $\times$ Home vs Away $\times$ Fertilisation & 0.19 & 0.03 & 7 & 3960.0 & 1.95 & 0.057 \\
\hline
\end{tabular}


Species $\times$ Country $\times$ Diversity

Species $\times$ Country $\times$ Species number

Species $\times$ Ecotype $\times$ Diversity

Species $\times$ Ecotype $\times$ Species number

Species $\times$ Home vs Away $\times$ Diversity

Species $\times$ Home vs Away $\times$ Species number

Country $\times$ Fertilisation $\times$ Diversity

Country $\times$ Fertilisation $\times$ Species number

Ecotype $\times$ Fertilisation $\times$ Diversity

Ecotype $\times$ Fertilisation $\times$ Species number

Home vs Away $\times$ Fertilisation $\times$ Diversity

Home vs Away $\times$ Fertilisation $\times$ Species number

Species $\times$ Country $\times$ Fertilisation $\times$ Diversity

Species $\times$ Country $\times$ Fertilisation $\times$ Species number

Species $\times$ Ecotype $\times$ Fertilisation $\times$ Diversity

Species $\times$ Ecotype $\times$ Fertilisation $\times$ Species number

Species $\times$ Home vs Away $\times$ Fertilisation $\times$ Diversity

Species $\times$ Home vs Away $\times$ Fertilisation $\times$ Species number

\begin{tabular}{|c|c|c|c|c|}
\hline Random effects & $\mathrm{n}$ & & Variance & $\mathrm{SD}$ \\
\hline Plot ID & & 762 & 0.00104 & 0.03227 \\
\hline Species composition & & 48 & 0.00005 & 0.00726 \\
\hline Bed ID & & 29 & 0.00021 & 0.01444 \\
\hline Residual & & & 0.01410 & 0.11875 \\
\hline
\end{tabular}

Significance was tested with the Satterthwaite approximation method. $n=4751$. Marginal $R^{2}=0.40$, conditional $R^{2}=0.45$. 
Extended Data Table 4 | Type-III Analysis of Variance table of the relationship between the difference in reproductive effort between

526 mixtures and monocultures and corresponding changes in plant interaction intensity and plant traits

\begin{tabular}{|c|c|c|c|c|c|c|}
\hline Factor & SS & MS & numDF & denDF & F-value & P-value \\
\hline Species & 0.817 & 0.117 & 7 & 1579.6 & 11.18 & $<0.001$ \\
\hline$\Delta \mathrm{N} \operatorname{lntC}$ & 0.534 & 0.534 & 1 & 1588.5 & 51.09 & $<0.001$ \\
\hline$\Delta$ Height & 0.212 & 0.212 & 1 & 1539.5 & 20.27 & $<0.001$ \\
\hline$\Delta$ Leaf area & 0.097 & 0.097 & 1 & 1588.8 & 9.31 & 0.002 \\
\hline$\triangle S L A$ & 0.096 & 0.096 & 1 & 1576.9 & 9.23 & 0.002 \\
\hline$\triangle \mathrm{LDMC}$ & $<0.001$ & $<0.001$ & 1 & 1578.8 & $<0.01$ & 0.984 \\
\hline Species $\times \Delta \mathrm{NIntC}$ & 0.509 & 0.073 & 7 & 1580.9 & 6.96 & $<0.001$ \\
\hline Species $\times \Delta$ Height & 0.233 & 0.033 & 7 & 1583.6 & 3.19 & 0.002 \\
\hline Species $\times \Delta$ Leaf area & 0.212 & 0.030 & 7 & 1580.6 & 2.89 & 0.005 \\
\hline Species $\times \Delta S L A$ & 0.245 & 0.035 & 7 & 1579.7 & 3.35 & 0.002 \\
\hline Species $\times \Delta$ LDMC & 0.259 & 0.037 & 7 & 1582.1 & 3.54 & $<0.001$ \\
\hline Random effects & $\mathrm{n}$ & Variance & SD & & & \\
\hline Plot ID & 637 & $<0.0001$ & $<0.0001$ & & & \\
\hline Bed ID & 29 & 0.0004 & 0.0198 & & & \\
\hline Residuals & & 0.0104 & 0.1022 & & & \\
\hline
\end{tabular}

528 Significance was tested with the Satterthwaite approximation method. $\mathrm{n}=1637$. Marginal $\mathrm{R}^{2}=0.16$, conditional $\mathrm{R}^{2}=0.19$. 
530 Extended Data Table 5 | Cultivar and seed supplier for the crop species used in the 531 experiment

\begin{tabular}{|c|c|c|c|c|}
\hline \multirow[t]{2}{*}{ Species } & \multicolumn{2}{|r|}{ Switzerland } & \multicolumn{2}{|c|}{ Spain } \\
\hline & Cultivar & Supplier & Cultivar & Supplier \\
\hline Avena sativa & Canyon & Sativa Rheinau & Previsión & INIA, Madrid \\
\hline Triticum aestivum & Fiorina & DSP, Delley & $\begin{array}{l}\text { Cabezorro } \\
\text { (BGE015403) }\end{array}$ & INIA, Madrid \\
\hline $\begin{array}{l}\text { Coriandrum } \\
\text { sativum }\end{array}$ & Indian & $\begin{array}{l}\text { Zollinger Samen, Les } \\
\text { Evouettes }\end{array}$ & wild type & $\begin{array}{l}\text { Semillas Cantueso, } \\
\text { Córdoba }\end{array}$ \\
\hline $\begin{array}{l}\text { Chenopodium } \\
\text { quinoa }\end{array}$ & n.a. & $\begin{array}{l}\text { Artha Samen, } \\
\text { Münsingen }\end{array}$ & Atlas & Algosur, Sevilla \\
\hline $\begin{array}{l}\text { Lupinus } \\
\text { angustifolius }\end{array}$ & Boregine & Aspenhof, Wilchingen & wild type & $\begin{array}{l}\text { Semillas Cantueso, } \\
\text { Córdoba }\end{array}$ \\
\hline Lens culinaris & Anicia & $\begin{array}{l}\text { Agroscope, } \\
\text { Reckenholz }\end{array}$ & de la Armuña & $\begin{array}{l}\text { Legumer SL, } \\
\text { Salamanca }\end{array}$ \\
\hline Camelina sativa & n.a. & $\begin{array}{l}\text { Zollinger Samen, Les } \\
\text { Evouettes }\end{array}$ & n.a. & $\begin{array}{l}\text { Camelina Company, } \\
\text { Madrid }\end{array}$ \\
\hline $\begin{array}{l}\text { Linum } \\
\text { usitatissimum }\end{array}$ & Lirina & Sativa Rheinau & wild type & $\begin{array}{l}\text { Semillas Cantueso, } \\
\text { Córdoba }\end{array}$ \\
\hline
\end{tabular}

532 
bioRxiv preprint doi: $h$ ttps://doi.org/10.1101/2020.06.12.149187; this version posted June 14, 2020. The copyright holder for this preprint (which was not certified by peer review) is the author/funder, who has granted bioRxiv a license to display the preprint in perpetuity. It is made available under aCC-BY-ND 4.0 International license.

534 Extended Data Fig. 1 | Reproductive effort of crops in response to the Home vs Away, 535 Fertilization, Country and Species number (2- vs 4-species mixtures) treatments

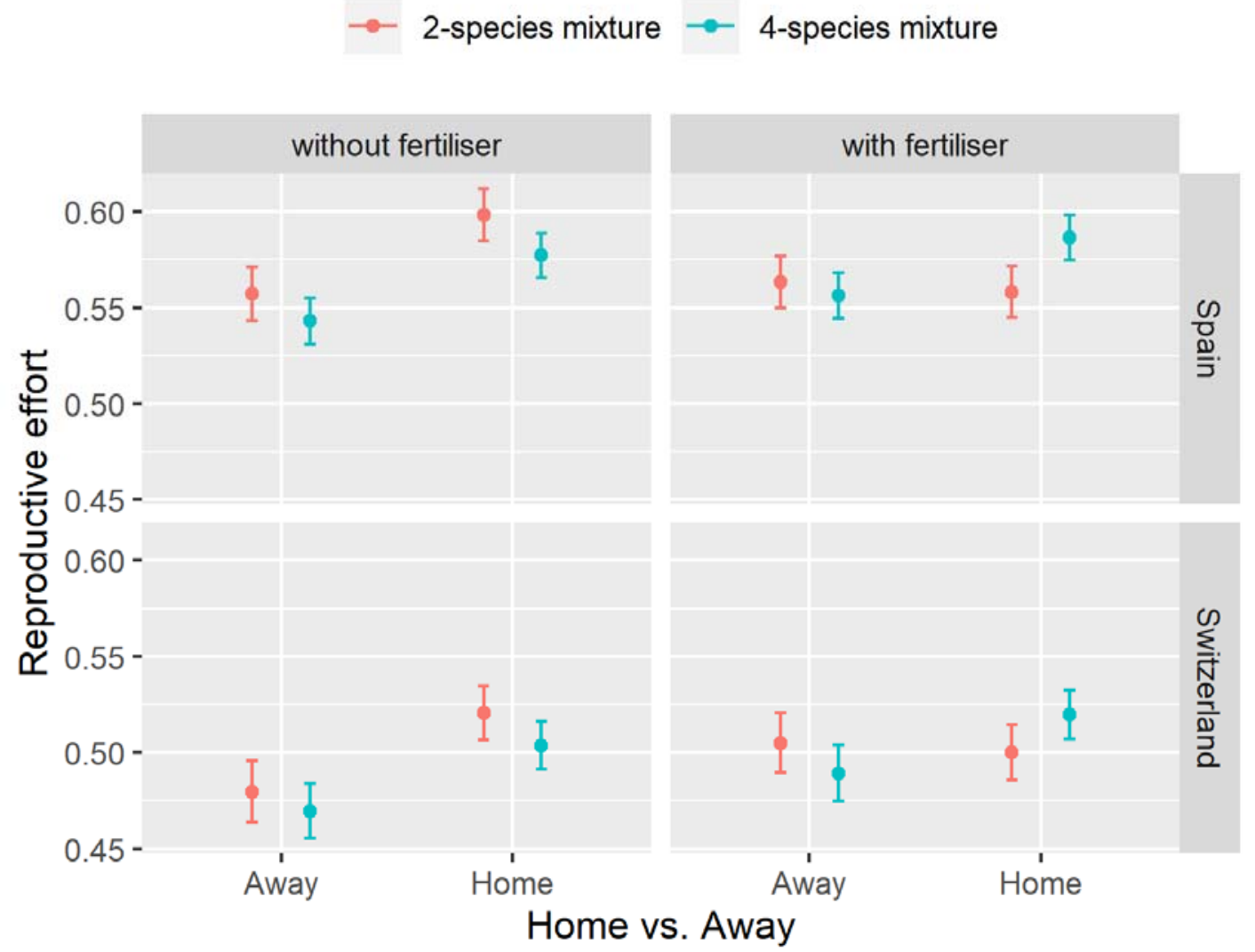


538 Extended Data Fig. $2 \mid$ Reproductive effort of the eight crop species planted in

539 communities of different species composition


Species were abbreviated as: Avena sativa $=A v$, Triticum aestivum $=\operatorname{Tr}$, Camelina sativa $=$

542 Ca, Coriandrum sativum $=$ Co, Lens culinaris $=$ Le, Lupinus angustifolius $=$ Lu, Linum usitatissimum $=L i$ and Chenopodium quinoa $=C h$. 
545 Extended Data Fig. 3 | Reproductive effort for eight crop species in their Home vs Away 546 environment

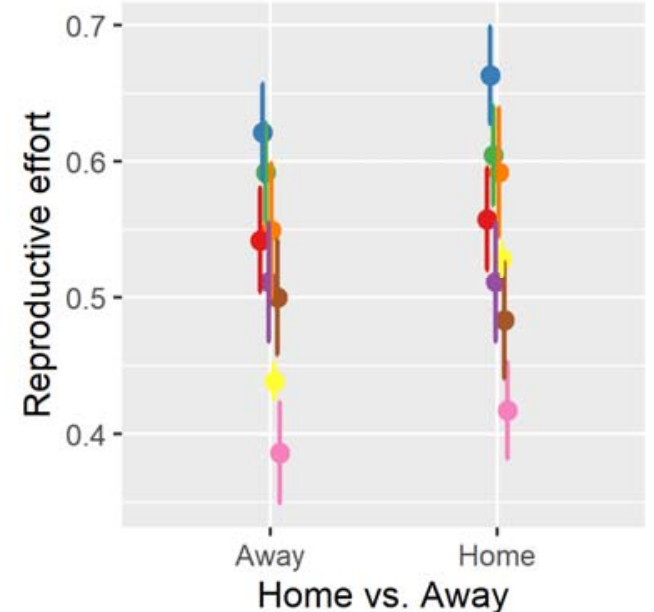

Crop species

$\rightarrow$ camelina

- coriander

- lentil

- linseed

- lupin

oat

- quinoa

- wheat

548 Reproductive effort quantifies the proportion of reproductive biomass, i.e. seed yield, from 549 total aboveground biomass produced by the Spanish cultivars in Spain and the Swiss cultivars 550 in Switzerland (Home) and vice versa (Away). 